This is a pre-copyedited, author-produced copy of an article that will be published in Climate Law (Brill), 2015.

\title{
The First Successful Climate Negligence Case: A Comment on Urgenda Foundation v. The State of the Netherlands (Ministry of Infrastructure and the Environment)
}

Jolene Lin

Associate Professor, Faculty of Law, University of Hong Kong

jolene@hku.hk

\begin{abstract}
On 24 June 2015, the Hague District Court issued a long-awaited judgment in the case of Urgenda Foundation $v$. The State of the Netherlands. The decision has been heralded as a historical landmark ruling. It marks the first time that a court has ordered a government to curb a state's greenhouse gas emissions. It is also the first case in which the tort of negligence has been successfully used to hold a state liable for failing to adequately mitigate climate change. This case commentary analyses key aspects of the decision and makes some observations about its significance for climate law and policy.
\end{abstract}

\section{Keywords}

Climate change; human rights; European Union law; international law; negligence.

\section{Introduction}

On 24 June 2015, the Hague District Court issued a long-awaited judgment in the case of Urgenda Foundation $v$. The State of the Netherlands (Ministry of Infrastructure and the Environment) (hereinafter, the Urgenda decision). ${ }^{1}$ The decision has been heralded as a historical landmark ruling, and rightly so. The Urgenda decision marks the first time that a court has ordered a government of the day to curb a state's greenhouse gas emissions. It is also the first case in which the tort of negligence has been successfully used to hold a state liable for its failure to adequately mitigate climate change. This case commentary begins by briefly setting out some background on climate litigation. It then sets out the facts of the case and analyses key aspects of the decision. It concludes with some remarks about the significance of the decision.

\section{Climate Litigation: A Brief Background}

Despite widespread acknowledgement of climate change as a major challenge to humanity and urgent calls to action by prominent scientists, economists, and even the Pope, states have been reluctant to adopt progressive, action-forcing targets and policies

\footnotetext{
${ }^{1}$ C/09/456689/HA ZA 13-1396, Judgment of 24 June 2015: $<$ http://uitspraken.rechtspraak.nl/inziendocument?id=ECLI:NL:RBDHA:2015:7196>; hereinafter, all paragraph numbers refer to those in this judgment unless otherwise stated.
} 
to reduce their GHG emissions. ${ }^{2}$ Frustrated by the lack of state action and concerned about the impacts of climate change, environmental NGOs have resorted to litigation as a means of generating judicial rulings that can fill the regulatory gap created by the inaction on the part of the executive and the legislature. ${ }^{3}$

Climate change litigation has comprised of legal actions against both public authorities and private entities. ${ }^{4}$ Legal action against public bodies has primarily been through judicial review. Judicial review is commonly understood to be judicial scrutiny of the legality of administrative decisions, and the role of the courts in such cases is to interpret the relevant legislation to ensure that it is implemented within statutorily conferred powers. A direct effect of judicial review has been to force environmental agencies and local authorities to include GHG accounting, emission-reduction measures, and adaptation measures in planning-permit applications and environmental impact assessment (EIA) procedures. ${ }^{5}$ In the seminal case of Massachusetts $v$. Environmental Protection Agency, the US Supreme Court ruled that the Clean Air Act gave the agency the authority to regulate tailpipe GHG emissions, and found the agency's rationale for not regulating such emissions to be inadequate. ${ }^{6}$ The US EPA was therefore obliged to regulate GHG emissions or provide a reasonable explanation for not doing so. In none of the climate change cases decided so far has a court directly addressed the issue of a state's duty to reduce its GHG emissions; nor has a court required a state to address climate change on a legal basis that was not a statutory mandate. The Urgenda decision is the first to do so.

Climate litigation against private corporations has relied on general theories of tort law, such as public nuisance and negligence. ${ }^{7}$ In the US, these private-law cases were not

\footnotetext{
${ }^{2}$ Coral Davenport and Laurie Goodstein, 'Pope Francis Steps Up Campaign on Climate Change, To Conservatives' Alarm', The New York Times (27 April 2015):

$<$ www.nytimes.com/2015/04/28/world/europe/pope-francis-steps-up-campaign-on-climate-change-toconservatives-alarm.html?_r=0>. UNEP's Emissions Gap Report 2014 is the fifth in a series that examines whether the pledges made by countries to reduce their GHGs are on track to meet the internationally agreed 2 degree Celsius target. It defines the 'emissions gap' as 'the difference between emission levels in 2025 and 2030 consistent with meeting climate targets versus the levels expected if country pledges are met'. Scientists estimate the gap in 2020 at up to 10 gigatonne (Gt) of carbon dioxide equivalent and up to $17 \mathrm{Gt}$ in 2030 . The UNEP report emphasizes that the gap can be closed if available mitigation opportunities are fully exploited as soon as possible:

$<$ www.unep.org/publications/ebooks/emissionsgapreport2014/>.

${ }^{3}$ For discussion, see, for example, Jacqueline Peel and Hari Osofsky, Climate Change Litigation: Regulatory Pathways to Cleaner Energy (Cambridge University Press, 2015).

${ }^{4}$ This section draws on Jolene Lin, 'Climate Change and the Courts', (2012) 32 Legal Studies 35, 37-38.

${ }^{5}$ See, for example, Gray v. Minister of Planning [2006] NSWLEC 720, widely regarded as an important breakthrough in Australian case law on climate change mitigation. This case established the legal requirement that coal-mining projects seeking approvals under the then in force Part $3 \mathrm{~A}$ of the Environmental Planning and Assessment Act 1979 must conduct EIAs that include consideration of the climate change impacts of the combustion of the produced coal. For discussion, see Anna Rose, 'Gray v Minister for Planning: The Rising Tide, of Climate Change Litigation in Australia' (2007) 29 Sydney Law Review 725; Brian J. Preston, 'The Influence of Climate Change Litigation on Governments and the Private Sector' (2011) 2 Climate Law 485.

${ }^{6}$ (2007) 127 S. Ct. 1438.

${ }^{7}$ See, e.g., Native Village of Kivalina, et al. v. Exxonmobil Corporation, et al., 696 F.3d 849 (9th Cir. 2012); or 663 F. Supp. 2d 863 (N.D. Cal. 2009) and American Electric Power Co., Inc., et al. v. Connecticut et al., 131 S. Ct. 2527 (2011); or Connecticut v. American Electric Power Co., No. 04 Civ. 5669 (SDNY Sept. 16, 2005).
} 
decided on their merits as they were summarily dismissed on the basis that they raised political questions. ${ }^{8}$ Further, across most jurisdictions and legal traditions, the difficulties of proving causation have doomed climate tort litigation from the outset. The Urgenda decision has bucked the trend, with the court deciding that legal causation and factual causation were one and the same, and omitting to apply the 'but for' test, because, it said, the test leads to perverse results in cases of cumulative environmental harm.

\section{The Urgenda Case: Facts}

Since the 2009 United Nations Framework Convention on Climate Change (UNFCCC) Conference of the Parties (COP) in Copenhagen, the target to limit average global temperature rise to no more than 2 degree Celsius above pre-industrial levels has become firmly entrenched in climate policy discourse. ${ }^{9}$ This temperature target was subsequently enshrined in the Cancun Agreements, ${ }^{10}$ wherein Annex I parties also endorsed an emissions reduction target of 25-40 per cent by 2020, compared to 1990 levels. The Inter-governmental Panel on Climate Change (IPCC), in its Fourth Assessment Report issued in 2007 as well as its Fifth Assessment Report issued in 2013, established that GHG concentrations in the atmosphere had to be stabilized at 450 parts per million in order to achieve the $2^{\circ} \mathrm{C}$ target. To be precise, the IPCC stated that "[e]missions scenarios leading to carbon dioxide-equivalent concentrations in 2100 of about $450 \mathrm{ppm}$ or lower are likely to maintain warming below 2 [degree Celsius] over the $21^{\text {st }}$ century relative to pre-industrial levels". ${ }^{11}$ The IPCC further states that "[1]imiting warming with a likely chance to less than $2 \mathrm{C}$ relative to pre-industrial levels would require substantial cuts in anthropogenic GHG emissions... Scenarios that are likely to maintain warming at below $2 \mathrm{C}$ are characterized by a 40 to $70 \%$ reduction in GHG emissions by 2050, relative to 2010 levels, and emissions levels near zero or below in 2100". ${ }^{12}$ The EU (including the Netherlands) initially focused on a reduction

\footnotetext{
${ }^{8}$ The political question doctrine is part of the doctrine of the separation of powers and provides that certain questions are political as opposed to legal, and thus must be resolved by the political branches rather than by the judiciary (Corrie v Caterpillar, Inc., 503 F. 3d. 974, 980 (9th Cir. 2007).

${ }^{9}$ In the first paragraph of the Copenhagen Accord, signatories pledge that " $[t] \mathrm{o}$ achieve the ultimate objective of the Convention to stabilize greenhouse gas concentration in the atmosphere at a level that would prevent dangerous anthropogenic interference with the climate system, we shall, recognizing the scientific view that the increase in global temperature should be below 2 degrees Celsius...enhance our long-term cooperative action to combat climate change"; Decision 2/CP.15 Copenhagen Accord: Report of the Conference of the Parties on its fifteenth session, held in Copenhagen from 7 to 19 December $2009 ;<$ http://unfccc.int/resource/docs/2009/cop15/eng/11a01.pdf >. For discussion of the history of the 2 degree Celcius target, see Samuel Randalls, "History of the 2C climate target", (2010) 1WIREs Climate Change 598-605.

${ }^{10}$ Decision 1/CMP.6 The Cancun Agreements: Outcome of the work of the Ad Hoc Working Group on Further Commitments for Annex I Parties under the Kyoto Protocol at its fifteenth session; $<$ http://unfccc.int/documentation/decisions/items/3597.php? such $=\mathrm{j} \&$ volltext $=\% 22$ cancun $\% 20$ agreements $\% 22 \#$ beg $>$.

${ }^{11}$ IPCC, 2014: Climate Change 2014: Synthesis Report. Contribution of Working Groups I, II and III to the Fifth Assessment Report of the Intergovernmental Panel on Climate Change (Core Writing Team, R.K. Pachauri and L.A. Meyer (eds)). IPCC, Geneva, Switzerland; Summary Report for Policymakers, pg. 20.

12 IPCC, 2014: Climate Change 2014: Synthesis Report. Contribution of Working Groups I, II and III to the Fifth Assessment Report of the Intergovernmental Panel on Climate Change (Core Writing Team, R.K. Pachauri and L.A. Meyer (eds)). IPCC, Geneva, Switzerland; pg. 82.
} 
target of 30 per cent by $2020 .^{13}$ However, following the COP in Copenhagen, the EU decided to use the 30 per cent target as an incentive to increase political will for a "global and comprehensive agreement for the period beyond 2012". ${ }^{14}$ The EU therefore made a pledge pursuant to the Copenhagen Accord to reduce its emissions by 20 per cent by 2020 (compared to 1990 levels), and to increase its reductions to 30 per cent by 2020 if "other developed countries commit themselves to comparable emission reductions and that developing countries contribute adequately according to their responsibilities and respective capabilities". ${ }^{15}$ In the international climate negotiations, the EU also adopts the policy that, in order to meet the 2 degree Celsius target, "developed countries as a group should reduce their GHG emissions below 1990 levels through domestic and complementary international efforts by 25 to $40 \%$ by 2020 and by 80 to $95 \%$ by $2050 \ldots "$.. In $2007-2009$, the Netherlands had an initial target of 30 per cent by 2020, but in 2010 it adopted a target derived from the EU's 20 per cent target. This derived target is expected to result in a total reduction for the Netherlands of 14-17 per cent in $2020 .{ }^{17}$ The EU, with the Netherlands, has committed itself to a 40 per cent reduction for 2030 and an 80 per cent reduction for $2050 .{ }^{18}$

On 20 November 2013, a Dutch foundation known as Urgenda, alongside 886 Dutch citizens, brought an action against the Netherlands for failure to adequately mitigate climate change. ${ }^{19}$ The dispute concerned the pace at which the Netherlands intends to reduce GHGs up to 2020 (and not the later targets). It focused on whether the Netherlands was acting unlawfully by pursuing a reduction target for 2020 that is lower than the range of 25-40 per cent endorsed by Annex I parties (which includes the Netherlands) in the Cancun Agreements as necessary for avoiding dangerous climate change.

Urgenda raised several grounds:

1. That the Netherlands failed to fulfill its duty to protect and improve the country's environment and its livability pursuant to article 21 of the Dutch Constitution.

2. That article 2 (right to life) and article 8 (right to respect for private and family life) of the European Convention on Human Rights imposed a positive duty on the Netherlands to take measures to guarantee these rights which are threatened by climate change.

\footnotetext{
${ }^{13}$ Para. 4.29.

${ }^{14}$ European Commission, Press Release, "Climate change: European Union notifies EU emission reduction targets following Copenhagen Accord”, 28 January 2010, <http://europa.eu/rapid/pressrelease IP-10-97 en.htm>.

${ }^{15}$ European Commission, Letter to the UNFCCC, "Subject: Expression of willingness to be associated with the Copenhagen Accord and submission of the quantified economy-wide emissions reduction targets for 2020",

$<$ http://unfccc.int/files/meetings/cop 15/copenhagen accord/application/pdf/europeanunioncphaccord ap p1.pdf $>$.

${ }^{16}$ Ibid.

${ }^{17}$ Para. 4.31.v.

${ }^{18}$ Para. 4.29.

${ }^{19}$ Urgenda, 'The Urgenda Climate Case Against the Dutch Government', <www.urgenda.n1/en/climatecase/>.
} 
3. That the Netherlands owed Urgenda and the rest of Dutch society a duty of care, the breach of which violated article $6: 162$ of the Dutch civil code. ${ }^{20}$

The state counter-argued that it 'cannot be forced at law towards Urgenda to adhere to the $25-40 \%$ target'. (The official website text is not always rendered in correct English; throughout this case note I have reproduced the original wording without modification.) Moreover, and in any case, it had not omitted to fulfill its duty of care. ${ }^{21}$

The discussion below will elaborate on certain key aspects of the decision, namely whether Urgenda had standing to bring the action, the relevance of the UNFCCC and related decisions of the Conference of the Parties, whether Urgenda could rely on articles 2 and 8 of the ECHR, and whether the Netherlands is liable in negligence for pursuing a GHG reduction target that is lower than $25-40 \%$ by 2020 (compared to 1990 levels).

\section{Standing}

Article 3:305a of the Dutch Civil Code provides that if a foundation or association with full legal capacity protects certain interests specified in its articles of association or bylaws, it can bring an action to protect similar interests of other persons. ${ }^{22}$ Article $3: 305 \mathrm{~b}$ further provides that the foundation or association may bring an action only after sufficient effort has been made to reach a settlement with the defendant.

The Netherlands conceded that the foundation had standing to represent the interests of the current generations of Dutch citizens, but argued that Urgenda had no standing to defend the rights or interests of current or future generations in other countries. ${ }^{23}$ The court found in favour of Urgenda on the ground that article 2 of Urgenda's by-laws demonstrates that the foundation prioritizes, but does not limit, its agenda to the Netherlands. ${ }^{24}$ Further, the foundation's by-laws state that Urgenda strives for a 'more sustainable society'. The court was of the view that the concept of a 'sustainable society' has an inherently global dimension and Urgenda thereby 'protect[ed] an interest that by its nature crosses national borders'. ${ }^{25}$ On the ground that the concept of sustainability has an inter-generational dimension, the court held that Urgenda's interests also included the protection and advancement of the rights of current and future generations to a safe and healthy environment. Having established that Urgenda's articles of association include the protection of the interests of future generations as well as the interests of individuals outside Dutch territory, the court held that Urgenda had sufficient standing to bring an action that aims to protect those interests. ${ }^{26}$

\footnotetext{
${ }^{20}$ Para. 4.35.

${ }^{21}$ Ibid.

${ }^{22}$ For discussion on environmental organizations' right of access to the civil courts in the Netherlands and the background to Article 3:305, see Hanna Tolsma et al, 'The Rise and Fall of Access to Justice in the Netherlands', (2009) 21(2) Journal of Environmental Law 309-321, at 311-313.

${ }^{23}$ Para. 4.5

${ }^{24}$ Para. 4.7.

25 Ibid.

${ }^{26}$ Para. 4.7.
} 


\section{Article 21 of the Dutch Convention}

Article 21 of the Dutch Constitution states: 'It shall be the concern of the authorities to keep the country habitable and to protect and improve the environment. ${ }^{27}$ Urgenda's argument was that the Netherlands, by adopting a GHG reduction target below the 2540 per cent range, was not fulfilling its article 21 constitutional duty. ${ }^{28}$

The court, using the same language as Urgenda used in its submissions, adopted the term 'duty of care' in lieu of 'concern'. ${ }^{29}$ It held that article 21 imposes a duty of care on the state but '[does] not provide certainty about the manner in which this duty of care should be exercised nor about the outcome ... in case of conflicting stipulations. The manner in which this task should be carried out is covered by the government's own discretionary powers' ${ }^{30}$ While the court explicitly sought to abstain from dictating to the government how it should fulfill its responsibilities pursuant to article 21 , it can be argued that the court did so indirectly when it decided the negligence claim, particularly the issue of whether the state had fallen below the standard of care with its current climate policy.

The court started with the premise that, 'in answering the question whether the State is exercising enough care with its current climate policy, the State's [article 21] discretionary power should also be considered'. ${ }^{31}$ It should be noted that throughout the judgement, the court uses terms such as "takes sufficient care" and "exercising enough care" as short-hand for "taking adequate measures to fulfill its duty of care". It went on to state that the state's discretionary power is not unlimited. ${ }^{32}$ Further: 'If, and this is the case here, there is a high risk of dangerous climate change with severe and lifethreatening consequences for man and the environment, the State has the obligation to protect its citizens from it by taking appropriate and effective measures. ... Naturally, the question remains what is fitting and effective in the given circumstances. ${ }^{33}$ The court rejected the state's argument that it was fulfilling its duty adequately with its adaptation measures, emphasizing that 'mitigation is vital for preventing dangerous climate change' and that 'adaptation measures will only allow the State to protect its citizens from the consequences of climate change to a limited level'. ${ }^{34}$ Thus, without ruling on whether the government had breached article 21 , the court provided clear direction on what, in its view, the government needed to do to address climate change in fulfillment of its constitutional obligation to protect the Dutch environment and improve livability for Dutch society.

\section{International Law and European Union Law on Climate Change}

\footnotetext{
27 The Constitution of the Kingdom of the Netherlands 2008 (published by the Ministry of the Interior and Kingdom Relations, Constitutional Affairs and Legislation Division in collaboration with the Translation Department of the Ministry of Foreign Affairs): <www.rijksoverheid.nl $>$.

${ }^{28}$ Para. 4.35 .

${ }^{29}$ Para. 4.36.

${ }^{30}$ Ibid.

${ }^{31}$ Para. 4.74.

${ }^{32}$ Ibid.

33 Ibid.

${ }^{34}$ Para. 4.75.
} 
Approximately half the decision ( 25 out of 58 pages) comprised an account of international law as well as EU law pertaining to climate change. To summarize this account, the Netherlands has signed and ratified the UNFCCC and the Kyoto Protocol. It has also endorsed the Bali Action Plan, the Cancun Agreements, the Doha Amendments to the Kyoto Protocol, and the Durban decision in which the UNFCCC parties agreed to conclude a legally binding climate change agreement no later than 2015. These decisions by the Conference of the Parties to the Convention are important milestones in the development of the international legal framework governing climate change. Urgenda relied on this body of international law to advance the claim that the Netherlands, as an Annex I party, has made international commitments to take the lead in combating climate change. It also relied on the fact that the Netherlands has endorsed the target of 25-40 per cent below 1990 levels by 2020, and 80-95 per cent below by 2050 , through the various decisions of the COP. By adopting a target derived from the EU's 20 per cent reduction target, Urgenda argues, the Netherlands is 'causing ... damage, from its territory, to current and future generations in the Netherlands and abroad'. In this context, Urgenda also raised the 'no harm' principle, which provides that no state has the right to use its territory in a manner that causes significant damage to other states.

It is not clear from the decision that Urgenda sought to argue that the Netherlands had breached its international legal obligations. The decision presents Urgenda's arguments as wavering between the propositions that, (1) the state is causing damage to others by its failure to adopt an adequate mitigation policy, despite its international legal obligations, and, (2) that the state is acting unlawfully towards Urgenda by failing to fulfill its international legal obligations. It should be noted that article 93 of the Dutch Constitution provides for the direct effect in the Netherlands of international law, but that the courts can decide whether a particular provision in international law has direct effect within the meaning of article 93.

In any case, the court held that 'When the State fails one of its obligations towards one or more other states, it does not imply that the State is acting unlawfully towards Urgenda' ${ }^{35}$ Further, Urgenda conceded that the 'no harm' principle, the UNFCCC, the Kyoto Protocol, and the various COP decisions 'do not have a binding force towards citizens (private individuals and legal persons)', and so Urgenda was precluded from relying on those provisions of international law. ${ }^{36}$ This reasoning also applied to Urgenda's claims that relied on EU law. The court held that the various EU directives on climate change, as well as article 191 of the Treaty on the Functioning of the European Union, do not confer rights on Dutch citizens vis-à-vis the state. ${ }^{37}$

However, the above discussion does not lead to the conclusion that international law and EU law were irrelevant to the court's decision. The principle of consistent interpretation requires courts to interpret national law in conformity with the rules of

\footnotetext{
${ }^{35}$ Para. 4.42.

${ }^{36}$ Ibid.

${ }^{37}$ Para. 4.44.
} 
international law so as to ensure that the latter are given effect. ${ }^{38}$ This principle is based on the presumption that the state, by ratifying a treaty, intends to fulfill its treaty obligations. Indeed, Dutch courts now adopt the broader view that every national norm is, in principle, subject to interpretation consistent with public international law. ${ }^{39}$ In the process of interpreting concepts such as 'reasonableness' in domestic law, a judge is required to take relevant international law into account. Through this route, international and EU climate change law have "a "reflex effect" in national law'. ${ }^{40}$ As will be seen in the discussion below on the negligence claim, the court established a ground-breaking precedent by using the internationally agreed ' 2 degree Celsius' target and the associated emission-pathway scenarios to determine whether a duty of care exists, and, if so, what the standard of care is.

\section{Articles 2 and 8 of the ECHR}

In order to bring a complaint under this heading, Urgenda had to satisfy the court that it is a 'victim' of a violation of the ECHR. This standing requirement is set down in article 34 of the ECHR. The term 'victim' has generated a rich jurisprudence. ${ }^{41}$ Briefly, a direct victim is one who is directly affected by an alleged violation of the ECHR and is able to demonstrate that the alleged violation had a practical effect on him or her. In exceptional cases, the European Court of Human Rights has allowed applications by 'indirect victims' (i.e. persons who are closely related to the victim, such as the victim's wife or brother, and who are affected by the alleged violation on the victim). While the European Court of Human Rights has been fairly liberal in its interpretation of standing, it will not entertain an in abstracto application or an actio popularis which alleges general human rights violations unconnected to any specific applicant. ${ }^{42}$

In the Urgenda decision, the court was of the view that Urgenda could not claim to be a direct or indirect victim of alleged violations of articles 2 and 8 of the ECHR because 'After all, unlike with a natural person, a legal person's physical integrity cannot be violated nor can a legal person's privacy be interfered with'. ${ }^{43}$ Further, even if Urgenda's objectives, as formulated in its articles of association, are interpreted to include the protection of Dutch and other European citizens from a violation of articles 2 and 8 of the ECHR, this does not suffice to give Urgenda the status of a 'potential

\footnotetext{
${ }^{38}$ For discussion of this principle, see Gerrit Betlem and Andre Nollkaemper, 'Giving Effect to Public International Law and European Community Law before Domestic Courts. A Comparative Analysis of the Practice of Consistent Interpretation', (2003) European Journal of International Law 14(3) 569-589.

${ }^{39}$ HR 16 November 1990, NJ 1992, 107, para. 3.2.3.

${ }^{40}$ Para. 4.43.

${ }^{41}$ See, for example, the cases of Ouardiri v Switzerland (Application No. 65840/09) and Ligue des Musulmans de Suisse and Others v. Switzerland (Application No. 66274/09) (popularly known as the Minaret Cases v Switzerland); The European Court of Human Rights declared the applications inadmissible on the ground that the applicants could not claim to be 'victims' of a violation of the Convention. In the court's view, the applicants' main complaint was that their religious beliefs had been offended which, on its own, does not satisfy the 'victim' requirement. The applicants could not show that the alleged violations of the Convention rights had any practical effect on them.

${ }^{42}$ Kevin Boyle, 'The European Experience: The European Convention on Human Rights', (2009) 40(1)

Victoria University of Wellington Law Review 165-174, p. 170.

${ }^{43}$ Para 4.45.
} 
victim' within the meaning of article $34 .^{44}$ The court thus found that Urgenda could not rely on the ECHR to uphold its claims. ${ }^{45}$ However, it held that the European Court of Human Rights jurisprudence on articles 2 and 8 were relevant to the court's interpretation of the standard of care in the negligence claim. ${ }^{46}$ The court referred to the 'Manual on Human Rights and the Environment' (published by the Council of Europe) as being an authoritative guide to the jurisprudence of the European Court of Human Rights on the relationship between the protection of human rights under the ECHR and the environment. ${ }^{47}$

\section{The Claim in Negligence}

\subsection{Duty of Care}

Article 6:162 of the Dutch Civil Code states that 'A tortious act is regarded a violation of someone else's right (entitlement) and an act or omission in violation of a duty imposed by law or of what according to unwritten law has to be regarded as proper social conduct, always as far as there was no justification for this behaviour. ${ }^{48}$ In determining whether Party A owes Party B a duty of care, or, in other words, whether a duty of care ought to be imposed on Party A, the court has to consider what 'proper social conduct' requires of Party A. In making this determination, the court is to be guided by the criteria set down in the landmark 'cellar-hatch ruling' (Kelderluikarrest $).{ }^{49}$ Briefly, the Kelderluik criteria are: First, how apparent is the danger? Second, how great is the chance that the danger will manifest itself? Third, how serious is the danger (for example, damage to health or property)? Finally, how costly or objectionable would it be for the defendant to take the necessary preventive measures?

In the Urgenda decision, the court derived a set of considerations from the Kelderluik criteria that would guide its determination of whether the Netherlands owed Urgenda a duty of care:

(i) the nature and extent of the damage ensuing from climate change;

(ii) the knowledge and foreseeability of this damage;

(iii) the chance that hazardous climate change will occur;

(iv) the nature of the acts (or omissions) of the State;

(v) the onerousness of taking precautionary measures; and

(vi) the discretion of the State to execute its public duties... ${ }^{50}$

In considering these factors, the court would also take into account the latest scientific

\footnotetext{
${ }^{44}$ In Norris $v$ Ireland (Application No. 10581/83), the applicant satisfied the victim test by demonstrating that he was a 'potential victim', that is, legislation existed that, if it were enforced against him, would result in a breach of his Convention rights, even though the legislation had not actually been enforced against him.

${ }^{45}$ Para. 4.45 .

${ }^{46}$ Para. 4.46.

${ }^{47}$ Para. 4.47.

48 Translation provided by "Dutch Civil Law", $<$ http://www.dutchcivillaw.com/legislation/dcctitle6633.htm $>$.

${ }^{49}$ HR, 6 November 1965, NJ 1966/136. The Caparo test would be the English law equivalent of the Kelderluik criteria; Caparo Industries plc v. Dickman [1990] 2 AC 605 [HL].

${ }^{50}$ Para. 4.63.
} 
knowledge, availability of feasible measures, and the cost-benefit ratio of adopting measures to discharge a duty of care.

In relation to the first and third factors, the court accepted that the IPCC's assessment reports, UNEP's 'emissions gap' 2014 report, and various European reports on climate change that were put before the court unequivocally established that 'the chances of dangerous climate change should be considered as very high - and this with serious consequences for man and the environment, both in the Netherlands and abroad'. ${ }^{1}$ The court also took into account the fact that the Netherlands 'had known since 1992, and certainly since 2007, about global warming and its associated risks' (second factor). ${ }^{52}$ In relation to the fourth factor, the court rejected the state's argument that it does not emit GHG gases and therefore cannot be said to cause climate change. ${ }^{53}$ The court held that the state had the power to implement laws and policies to control Dutch GHG emissions. In fact, it said, society depended on the government to put appropriate measures in place to make a transition towards sustainability and to reduce GHG emissions. Finally, the court took into account the fact that by signing the Kyoto Protocol, the Netherlands had accepted the obligation to reduce the state's emissions to prevent dangerous climate change.

The court then considered if the adoption of precautionary measures would be too onerous for the state, taking into account the technical feasibility and cost-effectiveness of precautionary measures. First, the court determined that mitigation measures are the only truly precautionary measures to adopt. ${ }^{54}$ It proceeded to accept Urgenda's argument that earlier action in the form of a more ambitious GHG reduction target was more cost-effective than delayed action (which would be the result of the Netherland's current target) on the basis of the scientific consensus established in the IPCC and UNEP findings. The court considered that the Netherlands had originally adopted the more ambitious 30 per cent target and there was no evidence that its decision in 2010 to adopt the less ambitious target was driven by cost considerations or difficulties of meeting the 30 per cent target. ${ }^{55}$ Hence, the court was of the view that the implementation of precautionary measures, in the form of a more ambitious target than the current 20 per cent, would not impose too onerous a burden on the state. ${ }^{56}$

The court's analysis in relation to the sixth factor has already been considered above (article 21 of the Dutch Constitution).

\subsection{The 'Drop in the Ocean' Argument}

To conclude the duty of care analysis, the court considered three arguments that the state put forth in support of its contention that a duty of care did not exist. The first is

\footnotetext{
${ }^{51}$ Para. 4.65.

${ }^{52}$ Ibid.

${ }^{53}$ Para. 4.66.

${ }^{54}$ Para 4.71.

${ }^{55}$ Para. 4.70.

${ }^{56}$ Para. 4.70.
} 
the infamous 'drop in the ocean' argument. ${ }^{57}$ The state argued that a higher target would result in 'a very minor, if not negligible, reduction of global greenhouse gas emissions. After all, whether or not the $2^{\circ} \mathrm{C}$ target is achieved will mainly depend on the reduction targets of other countries with high emissions. More specifically, the State relies on the fact that the Dutch contribution to worldwide emissions is currently only $0.5 \%,{ }^{58}$

The court rejected this argument. Its reasoning deserves to be reproduced in full:

It is an established fact that climate change is a global problem and therefore requires global accountability. ... It compels all countries, including the Netherlands, to implement the reduction measures to the fullest extent ... possible. The fact that the amount of the Dutch emissions is small compared to other countries does not affect the obligation to take precautionary measures ... After all, it has been established that any anthropogenic greenhouse gas emission, no matter how minor, contributes to an increase of $\mathrm{CO} 2$ levels in the atmosphere and therefore to hazardous climate change. Emission reduction therefore concerns both a joint and individual responsibility of the signatories to the UN Climate Change Convention.... Moreover, it is beyond dispute that the Dutch per capita emissions are one of the highest in the world. ${ }^{59}$

\subsection{Carbon Leakage and Competitiveness Concerns}

The second argument advanced by the state concerned carbon leakage, and the third was that a more stringent reduction target would place Dutch businesses at a competitive disadvantage in the global economy. ${ }^{60}$ The court rejected the carbon leakage argument on the basis that a recent assessment by the European Commission concluded that there was no evidence of carbon leakage as a result of the EU's climate change policies. ${ }^{61}$ As for the competitiveness argument, the court held that the state had failed to provide adequate supporting evidence: it had not clearly indicated the businesses it was referring to or how a stricter climate policy would affect the competitiveness of Dutch businesses and multinational corporations vis-à-vis their nonDutch counterparts. This argument was also rejected.

\subsection{Standard of Care}

Having concluded that the state owed Urgenda a duty of care to take mitigation measures, the court proceeded to define the $450 \mathrm{ppm}$ scenario as the standard of care. ${ }^{62}$ It concluded that, in order for the state to fulfill its duty of care, it was obliged to implement measures in line with keeping the level of GHGs in the atmosphere below $450 \mathrm{ppm}$ in order to avoid dangerous climate change.

\footnotetext{
57 Jacqueline Peel, 'Issues in Climate Change Litigation', (2011) 5(1) Carbon and Climate Law Review 15 .

${ }^{58}$ Para. 4.78 .

${ }^{59}$ Para. 4.79. Also see a similar reasoning in Justice Steven's opinion in Massachusetts v. Environmental Protection Agency (2007) 127 S.Ct. 1438, p. 21.

${ }^{60}$ Paras. 4.81 and 4.82 .

${ }^{61}$ The Court relied on the 'Communication from the Commission to the European Parliament, the Council, the European Economic and Social Committee and the Committee of the Regions: A Policy Framework for Climate and Energy in the period from 2020 to 2030', <http://eur-lex.europa.eu/legalcontent/EN/TXT/PDF/?uri=CELEX:52014DC0015\&from=EN>.

${ }^{62}$ Para. 4.83 .
} 


\subsection{Breach of the Duty of Care}

The court held that, with its current reduction target, the state failed to meet the standard of care, because the target would lead to the postponement of mitigation measures and to a greater accumulation of GHGs, which would cost more to mitigate in the future and increase the risk of exceeding the 450 ppm threshold. ${ }^{63}$

\subsection{Causation}

In a traditional negligence analysis, Party B would have to prove that Party A's breach of its duty of care caused B's injury. In the Urgenda decision, this analysis to establish causation did not take place, and it is not clear why not. In its submissions, Urgenda sought to draw an analogy between the facts of the case and those in the 'Kalimijnen ruling' ${ }^{64}$ In the Kalimijnen case, the dumping of chloride (salt) by various parties in Germany, France, the Netherlands, and Luxembourg had led to extensive pollution of the Rhine River. The dumping of chloride by one of those parties could not have caused the pollution. It was established that the pollution was the cumulative result of the acts of various parties. If the classic 'but for' test were applied to establish causation, no party would have been found liable. The end result would have been a failure to stop the pollution and protect the riparian rights of those affected. The court eventually ruled that, in such cases of 'cumulative causation', individual parties will be held liable for their 'share' in causing the harm and will pay a corresponding share of the damages awarded. In the Urgenda decision, it is evident that the court applied the logic of the Kalimijnen ruling to establish causation (as indicated by its reference to paragraph 4.79 of its own judgment, where the state's 'drop in the ocean' argument was rejected). However, the court did not set out its reasoning, simply holding that, based on the duty of care analysis, 'a sufficient causal link can be assumed to exist between the Dutch greenhouse gas emissions, global climate change and the effects (now and in the future) on the Dutch living climate'. ${ }^{65}$

\subsection{Separation of Powers}

The court was keen to emphasize that the Dutch constitutional arrangement sought to provide a system of checks and balances on how each branch of government carried out its duties and functions. In this regard, the role of the court is to confer legal protection and determine disputes between parties, 'which it must do if requested to do so' (emphasis in original) ${ }^{66}$ In situations where the court's determination of a dispute is likely to lead to consequences for third parties not party to the proceedings, the court will exercise restraint. ${ }^{67}$ In this regard, the court took into account the state's argument that allowing Urgenda's claim regarding the reduction target would damage the Netherland's negotiating position at the Paris climate change conference at the end of

\footnotetext{
${ }^{63}$ Para. 4.85.

${ }^{64}$ R. H. J. Cox, 'The Liability of European States for Climate Change', (2014) 30(78) Utrecht Journal of International and European Law 125, p. 132.

${ }^{65}$ Para. 4.90.

${ }^{66}$ Para. 4.95.

${ }^{67}$ Para. 4.96.
} 
2015. However, apart from acknowledging that 'the court should exercise restraint given the possibility that the consequences of the court's intervention are difficult to assess', the court did not explain how this factor influenced its decision. ${ }^{68}$

Ultimately, the court ordered the state to reduce Dutch GHG emissions by at least 25 per cent by 2020 (compared to 1990 levels) and to pay Urgenda's costs. ${ }^{69}$ It may be that the court's 'exercise of restraint' was to impose on the state a target at the lower limit of the 25-40 per cent range, even though the court repeatedly noted that, based on the evidence submitted by the state, it was an established fact that the state would not face significant difficulties in reducing emissions by 30 per cent by 2020 .

\section{Conclusion}

This commentary on the Urgenda decision sought to shed light on the key aspects of this ruling, which is truly historic because it marks the first time that a negligence suit has been successfully brought against a government for its failure to mitigate climate change. The way in which the court determined the existence of a duty of care involved a superb grasp of current scientific knowledge of climate change and its consequences. The establishment of a standard of care, with reference to the $450 \mathrm{ppm}$ scenario as well as the 2 degree Celsius target, has created a useful precedent for similar cases in the future. Scholars and climate change activists will be perusing this decision earnestly for some time to come.

${ }^{68}$ Para. 4.100.

${ }^{69}$ Para. 5.1. 